\begin{tabular}{l} 
RCCS \\
\hline Annual Review
\end{tabular}

\section{RCCS Annual Review}

A selection from the Portuguese journal Revista Crítica de Ciências Sociais

4 | 2012

Issue no. 4

\title{
State-Market Relations in the Perspective of Original Institutionalism
}

\section{Jorge Bateira}

Translator. Karen Bennett

\section{(2) OpenEdition}

\section{Journals}

Electronic version

URL: http://journals.openedition.org/rccsar/440

DOI: $10.4000 /$ rccsar.440

ISSN: $1647-3175$

Publisher

Centro de Estudos Sociais da Universidade de Coimbra

Electronic reference

Jorge Bateira, « State-Market Relations in the Perspective of Original Institutionalism », RCCS Annual Review [Online], 4 | 2012, Online since 01 October 2012, connection on 30 April 2019. URL : http:// journals.openedition.org/rccsar/440 ; DOI : 10.4000/rccsar.440 


\title{
Jorge Bateira
}

School of Economics, University of Coimbra

\section{State-Market Relations in the Perspective of Original Institutionalism ${ }^{*}$}

\begin{abstract}
This article summarises the main arguments of a critical literature that radically questions the neoclassical economic theory of state-market relations and identifies the fundamental methodological weaknesses of this school of thought. As an alternative, it presents an interpretation of the methodology on which Original Institutionalism, the political economy movement launched by Thorstein Veblen, is based. The article proposes an understanding of the economy and markets as emerging institutions, reflecting a metaphysics of social systems that views the latter as complex, self-organised and interactive processes. The state-market relationship is analysed in light of this institutional interactivity. Highlighting the co-evolution of state and market, the article attributes a central role to industrial policy in economic development processes.
\end{abstract}

Keywords: state; institutionalism; institutions; market; industrial policy; state-market relation.

\section{Introduction}

From World War II to the 1970s, a type of capitalist economy prevailed in the West that was known as a mixed economy, an economy in which the state regulated markets fairly tightly, redistributed the income generated through taxation and social benefits, protected citizens from some risks and owned companies in some sectors of the economy.

State intervention in the functioning of markets was justified by the notion that markets do not, in practice, work exactly in accordance with the General Equilibrium Model (GEM) proposed in the $19^{\text {th }}$ century by Leon Walras, one of the founders of the neoclassical current. Vilfredo Pareto, his disciple, developed Walras's ideas through a particular approach to individual preferences: preferences determine the individual's choices and ultimately his well-being; and the utility that an individual attributes to goods cannot be measured or compared with that of another, but merely ordered. Starting from these assumptions, he defined a principle which, in its strongest version, claims the following: "The group of individuals increases its welfare in moving from $a$ to $b$ if at least one individual is better off in b and no individual is worse off" (Acocella, 2000: 23). Although this is a value judgement, the "Pareto principle" was enshrined by economists as their "efficiency" concept. Indeed, economists went even further and adopted a formulation known as the "Pareto optimum," implicitly suggesting that this involved a desirable social state: "A social state $a$ is Pareto

\footnotetext{
* Article published in RCCS 95 (December 2011).
} 
'optimal' if in moving from that state to any other state it is not possible to increase the welfare of one member of society without worsening the condition of at least one other" (ibidem: 24). Moreover, neoclassical theory ended up establishing a correspondence between the Pareto optimum and the equilibrium of a perfectly competitive market. This correspondence was expressed in two theorems which, applied to a market system, stated the following:

1. In an economic system with perfect competition and complete markets, a competitive equilibrium, if it exists, will be Pareto optimal.

2. If there are complete markets and certain conditions are met regarding individual utility functions [...] and production functions [...], every Pareto-optimal state can be realised as the outcome of a competitive equilibrium through an appropriate redistribution of resources (initial endowments) among individuals. (ibidem: 72-3)

Based on the first theorem, neoclassical theory supports public intervention whenever markets fail to deliver an efficient allocation of resources. This is known as a "market failure." Within certain limits, the second theorem justifies public intervention in the redistribution of income to promote equity without compromising efficiency. ${ }^{1}$

With the rise of neoliberal thinking in the 1970s, it was to be expected that the Austrian school (Menger, Hayek), which was very critical of public intervention in markets, would replace the synthesis achieved by Paul Samuelson between his (revisionist) interpretation of the work of Keynes and neoclassical theory. But the fact is that the work of Hayek had always been relegated to the background in university economics departments. Chang gives a plausible explanation for this:

Given that the Austrian-libertarian tradition had been on the margin of intellectual respectability until the 1970s, the neo-liberals could not afford to do without the 'scientific' respectability that neoclassical economics carried, in return for which the Austrian-libertarian tradition supplied the popular appeal that neoclassical economics could never dream of supplying itself (whoever died in the name of Pareto Optimality or General Equilibrium?). (2002: 541)

Thus, instead of an academic revolution led by the Austrian school, there has been, since the 1970s, a reform of neoclassical theory designed to contain, or even revert, traditional

\footnotetext{
${ }^{1}$ The lack of realism in Pareto's first theorem is obvious. I highlight one of the weakest assumptions of this axiom: the existence of a system of complete markets, i.e., all economic activity is fully regulated through perfect markets. However, reality shows us that it is not like that, and that externalities, public goods, transaction costs and asymmetrical information are typical situations of real markets. As for the second theorem, it is important to emphasise that it is not possible to separate the resource allocation function from the income redistribution function. For a more detailed critique of these theorems, see Acocella (2000: ch. 5).
} 
arguments in favour of state intervention. Controlling political power, and using the narrative about the unsuitability of Keynesian policies to confront the oil crisis of 1973, supporters of the neoliberal reshaping of society mobilized neoclassical theory in their favour. If the latter was already aloof from the actual problems confronted by political decision makers, from this moment on it gradually turned into a sterile formalism. At the same time, the traditional analysis of market failures was modified in order to sanction a more restricted number of public interventions, ${ }^{2}$ on the one hand, and on the other, completed with a new domain, that of "state failures." In this case, the limitations or perverse effects of public policies began to be theorized.

Thus, from the 1980s, there appeared a renovated version of neoclassical theory based on Walras's conceptual framework. Inspired by late $19^{\text {th }}$ century mechanical physics, the General Equilibrium Model (GEM) only recognises the action of individuals as a source of causality, thereby ignoring the complex systemic nature of markets. Moreover, to sustain the convergence of markets towards equilibrium, it only considers negative feedback effects as a consequence of the action of economic agents. Despite its evident weaknesses, neoclassical economic theory has remained hegemonic in economics programmes and textbooks. Nevertheless, innovative research has been carried out on the margins of the dominant paradigm. One minority stream that has been revived in recent decades is Original Institutionalism, the form of institutionalism initiated by Thorstein Veblen (Hodgson, 2004). The present article is affiliated to this stream.

The first section highlights some of the critiques of neoclassical theory and identifies its fundamental methodological weaknesses. The second section briefly summarises the methodology underlying Original Institutionalism, while the third section develops an institutionalist understanding of the market and the state-market relation based on a metaphysics of process and emergent ontology. ${ }^{3}$ The conclusion discusses one fundamental implication of this institutionalist approach, namely the central place that the state and

\footnotetext{
${ }^{2}$ The existence of externalities - actions of an economic nature that generate (physical and/or economic) effects that affect other agents that do not receive compensation - is one of the most debated market failures. For a more detailed critique of externality theory, see Vatn and Bromley (1997).

${ }^{3}$ For process metaphysics all reality is "change." "For the process philosopher, process has priority over product - both ontologically and epistemically" (Rescher, 2000: 6). Moreover, the most basic processes tend to be organized into open systems. With evolution they give rise to new systems, endowed with new properties, which include those of the lower level. Thus, all reality, including sociocultural reality, is organized into emergent levels, which are autonomous but necessarily interdependent. This is a process-based emergentist ontology (Campbell, 2009).
} 
industrial policy occupy in the development processes that have taken place in recent decades.

\section{A Critique of the Foundations of Neoclassical Theory}

Three decades after it was demonstrated that it was impossible to induce a unique stable equilibrium in a GEM distant from economic reality, the textbooks used for teaching economics, particularly public economics, have remained immune to the devastating critiques that have accumulated (Rizvi, 2006). For example, Kirman (1989) shows that, instead of convergence to equilibrium, instability is part of the model, even when we admit that consumers have identical preferences. Ackerman describes the intellectual failure of the general equilibrium model in these terms:

The basic finding about instability [...] is that almost any continuous pattern of price movements can occur in a general equilibrium model. [...] Not only does general equilibrium fail to be reliably stable; its dynamics can be as bad as you want them to be. (2004: 16)

In fact, the critique of the foundations of neoclassical theory not only destroys the idea that a market system tends towards a state of unique stable equilibrium, it also goes further. Using models of interaction between economic agents, and incorporating non-linearity into the equations, it arrived at results with properties identical to those of complex physical phenomena, such as the formation and bursting of speculative bubbles. ${ }^{4}$ Thus, Ackerman concludes:

Theoretical analysis to date [...] has shown that stability is simply not an endogenous mathematical property of market economies under all initial conditions. [...] If it is so difficult to demonstrate that stability is endogenous to a market economy, perhaps it is exogenous. (2004: 30)

Therefore, instead of trying to explain the functioning of markets from the behaviour of individuals alone, in production or consumption, it makes sense to relate those behaviours to realities which influence or partly determine them, particularly forms of extra-price coordination and so-called institutions. As we shall see in the next section, this is not just about finding exogenous stability factors (outside the market) for the simple reason that such factors, existing through a necessary relationship with the activities of economic agents, are also part of the institution that is the market.

\footnotetext{
${ }^{4}$ It should be noted that central banks continue to do simulations with general equilibrium models, the socalled Dynamic Stochastic General Equilibrium (DSGE) models (Tovar, 2008).
} 
The integration of the connection between market agents, institutional norms, companies and other organizations into economic analysis constitutes a crucial demarcation line between neoclassical economics and other theoretical currents, such as the institutionalist political economy launched by Veblen. Within neoclassical economics, market analysis takes as reference a preference-focused individual, behaving according to a calculative rationality that aims to maximise the use of the goods and services that he consumes. The market is seen as the set of exchanges of a homogeneous product without the intervention of money. On the contrary, institutional political economy assumes the sociocultural nature of the market, seeing it as an emergent reality, structured into different levels of organization and complexity. ${ }^{5}$ For example, while neoclassical economics treats companies as functions of production, institutionalist political economy sees the company as an organization with properties that are not reducible to those of the individuals that constitute it, and as a central actor in the market. ${ }^{6}$ According to this logic, the market is a complex social system, made up of relations between individuals, companies, institutional norms and culture. It is a sociocultural system that emerges through causal interactions between these different realities.

We should recall that introductory economics textbooks do not discuss the reality of markets beyond the well-known supply and demand graphs. For this reason, Hodgson's perplexity is well justified when he claims: "No fewer than three Nobel Laureates have noted the paradoxical omission of discussion of markets institutions in economics literature" (2008: 251).

Neoclassical theory also presents great weaknesses on the level of the individual. Since Lionel Robbins, economists have assumed that economic behaviour translates into a rational choice of the means to achieve ends that are considered a given. Ultimately, this is a calculative instrumental rationality, applicable to any field where optimization is subject to limitations, whether these are resources, rules or others' behaviours (Smith, 2008). The fact

\footnotetext{
5 'Emergentism claims that a whole is 'something more than the sum of its parts', or has properties that cannot be understood in terms of the properties of the parts. Thus, emergentism rejects the idea that there is any fundamental level of ontology. It holds that the best understanding of complex systems must be sought at the level of the structure, behavior and laws of the whole system and that science may require a plurality of theories (different theories for different domains) to acquire the greatest predictive/explanatory power and the deepest understanding." (Silberstein, 2002: 81).

${ }^{6}$ It is important to remember that the New Institutionalism is quite different from Original Institutionalism. The former was launched by Oliver Williamson (1975) with the purpose of filling gaps in neoclassical thought. For Williamson, institutions frame and foster individual behaviours but the interdependency between the two levels is ignored. For a critique of New Institutionalism, see Vira (1997).
} 
that rational choice can be easily formalized in mathematical terms was decisive for the academic respectability that it acquired, and this is probably one of the reasons why other disciplines imported it.

However, in the mid $20^{\text {th }}$ century, Herbert Simon (1959), going beyond the critiques of the theorization of economic agents' preferences, challenged the way neoclassical theory sees the human mind and rational behaviour. In particular, he stressed the great limitations of decision-making processes when alternatives are not fixed from the outset and have to be sought out, and also when it is a matter of predicting the consequences of each alternative. Simon's point of view, while accepted by some currents of critical thinking, has long ceased to be relevant given the advances in research into neurophysiology and psychology (Damásio, 1999; Bandura, 2001). ${ }^{7}$ In fact, human cognition, constructed through a sociability sustained by emotions, is far too complex for the critique of the foundations of neoclassical economic theory to concentrate on the computational limitations of the mind and the impossibility of accessing all relevant information.

The institutionalist political economy initiated with Veblen goes deeper. First of all, it recognises that human beings only become people through sociability, so that they themselves, and the sociocultural environment in which they live, have to be seen as interdependent and co-evolving. Moreover, it understands that individual decisions are never the result of a utilitarian, atomistic and isolated rationality. Inspired by the pragmatism of Charles S. Peirce, Original Institutionalism assumes that human rationality is revealed through action, through our way of being in the world (Kilpinen, 2003). According to this view, developed especially by John Dewey, means and ends should be seen as interdependent and evolving: "An end, or effect, soon becomes a means, or cause, for what follows. [...] nothing happens which is final in the sense that it is not part of any ongoing stream of events" (Whitford, 2002: 337).

In fact, human behaviour is not a sequence of discrete decisions in which the choice of means is determined and evaluated on the basis of known ends. On the contrary, human behaviour is a process in which the ends in sight also depend on the situation at hand and the means that are available. This interdependence is clearly visible when new needs, or ends, are generated by new technologies. Thus, overcoming the analytical distinction

\footnotetext{
${ }^{7}$ It should be pointed out that Herbert Simon was strongly influenced by the expansion of cybernetics and by computation technology. For a more detailed critique, see Bateira (2006).
} 
between means and ends, Dewey's pragmatism holds that they are not separate. Rather, it is by experiencing a process in which results are gradually anticipated that human beings reveal their rationality, provisionally deliberating about everything that is at stake, i.e. about results, ends, means and the course of action itself. This dynamic understanding of human rationality is radically incompatible with rational choice theory, even in those of its versions that were revised to accommodate the criticisms levelled at it.

Finally, denying the distinction between positive and normative economics enshrined in textbooks, institutionalist political economy adopts a research methodology centred on concrete economic processes and on the continual subjection of theory to the test of reality and the results of the policies that it proposes. Inspired by Peirce's pragmatism, it develops "a self-correcting inquiry [which] produces experimentally determined, operationally feasible solutions to specific problems in a dynamic, changing economic system. The result is a better understanding of the reality of change in the evolving economy" (Liebhafsky, 1993: 749). ${ }^{8}$ For institutionalist economists of this lineage, there is not a positive economics that describes, analyses and explains, and a normative economics that makes judgements about political options because, in fact, human rationality always involves some kind of judgement, albeit provisional, about means and ends (Rescher, 2004).

\section{The Methodology of Original Institutionalism}

In order to understand the complexity of the "individual-social system" nexus, it is essential to go back to Veblen's institutionalist political economy, a current that was very influential and perhaps even mainstream in the US academia in the interwar period. The central ideal of Veblen's institutionalism is aptly summarised in the following paragraph:

The growth and mutations of the institutional fabric are an outcome of the conduct of the individual members of the group, since it is out of the experience of the individuals, through the habituation of individuals that institutions arise; and it is in this same experience that these institutions act to direct and define the aims and the end of the conduct. (1994b: 243)

The last sentence of this quotation shows that, for Veblen, institutions have autonomy and a causal power that influences the conduct of individuals. However, he also rejects any

\footnotetext{
${ }^{8}$ As Mirowki stated, "institutionalist economics was the offspring of an entirely distinct philosophical tradition from that which gave rise to neoclassical economics. These two traditions have a profound conflict over their respective images of a 'science', and therefore profoundly incompatible images of 'economic man' and 'rationality'” (1987: 1002).
} 
structural determinism when he asserts that "institutions arise" out of the sociability of individuals. This is one of the rare references to the emergence of institutions in his work. Veblen kept aloof from the philosophical debate of his time about the ontological relationship between different levels of reality (matter, life, person, society), and did not commit himself to a particular ontology of social reality. ${ }^{9}$ Even so, it seems clear that he rejected both methodological individualism and methodological collectivism (Hodgson, 2004: ch. 8). Despite the ambiguities of some of his formulations, Veblen viewed institutions as evolving sociocultural entities generated by an upward causality from the action of individuals; in the same process, institutions exert a downward causality on individuals' ideas, preferences and behaviours.

Not having joined the debate on the ontology of social reality, Veblen attributed a vague, broad sense to the concept of "institution," focusing his analysis primarily on structures of a cultural nature. ${ }^{10}$ Despite his in-depth discussion of the business firm, he did not concern himself with markets. For an analysis of markets in which the systemic dimension of institutions is touched upon, we need to revisit the work of Karl Polanyi.

Karl Polanyi (1944) criticised the classical economists for their atomistic view of the individual and for identifying the exchange of products in archaic societies with the market. In his view, the institutional transformations of the $19^{\text {th }}$ century in Great Britain, induced by the Industrial Revolution, gave rise to a capitalist society that began to treat work, nature and money as (fictitious) commodities. According to Polanyi, "to include them in the market mechanism means to subordinate the substance of society itself to the laws of the market" (1944: 71).

Polanyi's institutionalist perspective was conveyed in more elaborate form in one of his last works:

The fount of the substantive concept [of economics] is the empirical economy. It can be briefly (if not engagingly) defined as an instituted process of interaction between man and his environment. (1957: 248)

A study of how empirical economies are instituted should start from the way in which the economy acquires unity and stability, that is the interdependence and recurrence of its parts. (ibidem: 250)

\footnotetext{
${ }^{9}$ For a discussion of emergentist ontology in social reality, see Weissman (2000).

${ }^{10}$ For a discussion of the ontology of cultural structures, see Bateira (2010).
} 
Acts of exchange on the personal level produce prices only if they occur under a system of price-making markets, an institutional setup which is nowhere created by mere random acts of exchange. (ibidem: 251)

These formulations show that Polanyi distinguished the interpersonal level of mercantile exchange from the level of institutional norms of the market. Further, Polanyi considered the two levels as simultaneously autonomous and interdependent: "institutional patterns and principles of behavior are mutually adjusted" (Polanyi, 1944: 49). Therefore, he criticised the founding fathers of political economy for ignoring society as an emergent reality endowed with its own causality. In this sense, Polanyi's thought on markets, the economy and society is not only institutionalist but also systemic.

More recently, the South Korean Ha-Joon Chang has shown the relevance of Original Institutionalism in the analysis of development processes. In a recent work, he calls attention to the causal relations, both upwards and downwards, involved in the development of societies. Recognising that the culture of a non-industrialized society seems unfavourable to industrial development, Chang disputes the idea that a "cultural revolution" is necessary for development to occur:

Though culture and economic development influence each other, the causality is far stronger from the latter to the former; economic development to a large extent creates a culture that it needs. Changes in economic structure change the way people live and interact with one another, which, in turn, changes the way they understand the world and behave. (2007: 200201)

He accepts that institutional norms and culture shape individuals and influence their behaviours. But at the same time, he was able to observe how, in various countries, the effects produced by economic policies on the interactions between individuals within companies, trade unions, state organizations and on other subsystems of society led to changes in those organizations, in the norms of institutions and in culture. It is within this conceptual framework of multi-level interdependencies, of an emergentist ontology, that the next section explores the concept of the market and its relationship with the state.

\section{State and Markets Co-evolve}

Let us begin with a basic question: What are markets? According to the interpretation of Original Institutionalism presented in this article, markets are social systems organized for the provisioning of a society. They emerge from the interaction between people who, 
performing specific roles, form organizations, networks of relations and norms regulating various activities (Figure 1). ${ }^{11}$

\section{Market A}

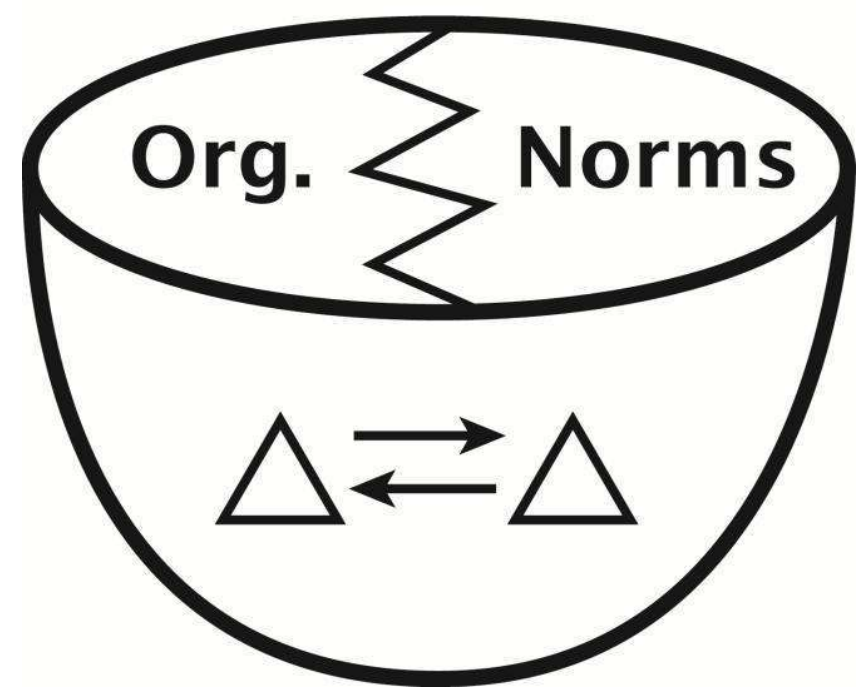

Figure 1 - The market as complex self-organized system Source: Bateira (2010)

To understand the nature of the market it is necessary to make an analytic distinction between individual interactions (the bottom) and the structures that emerge from them, namely organizations (business networks, firms, associations or regulatory bodies) and institutional norms (laws and regulations, informal rules, business culture). Individuals and market structures form a complex self-organized systemic whole, in a word, an "institution." This was also the perspective of the social researchers who worked with Polanyi in his late years. According to one of them,

all societies, viewed as self-maintaining social systems, have certain fundamental requirements which must be met if they are to continue in operation. [...] Furthermore, all societies in fact have structures of social relations through which this supply is maintained, and in any given case that structure (or structures) is its economy. (Hopkins, 1957: 287)

At this point, it should be stressed that the institutions of every society differ in terms of their nature, complexity and functions, and this entails relations of inclusion. Thus, firms are (micro) institutions that operate in the markets, which are (meso) institutions, subsystems of

\footnotetext{
${ }^{11}$ It is important to remember that markets, understood as institutions, only appeared with long-distance sailing and the advent of the nation state.
} 
the economy. The latter is the (macro) institution that ensures the provision of both market and non-market goods and services to society (Figure 2). ${ }^{12}$

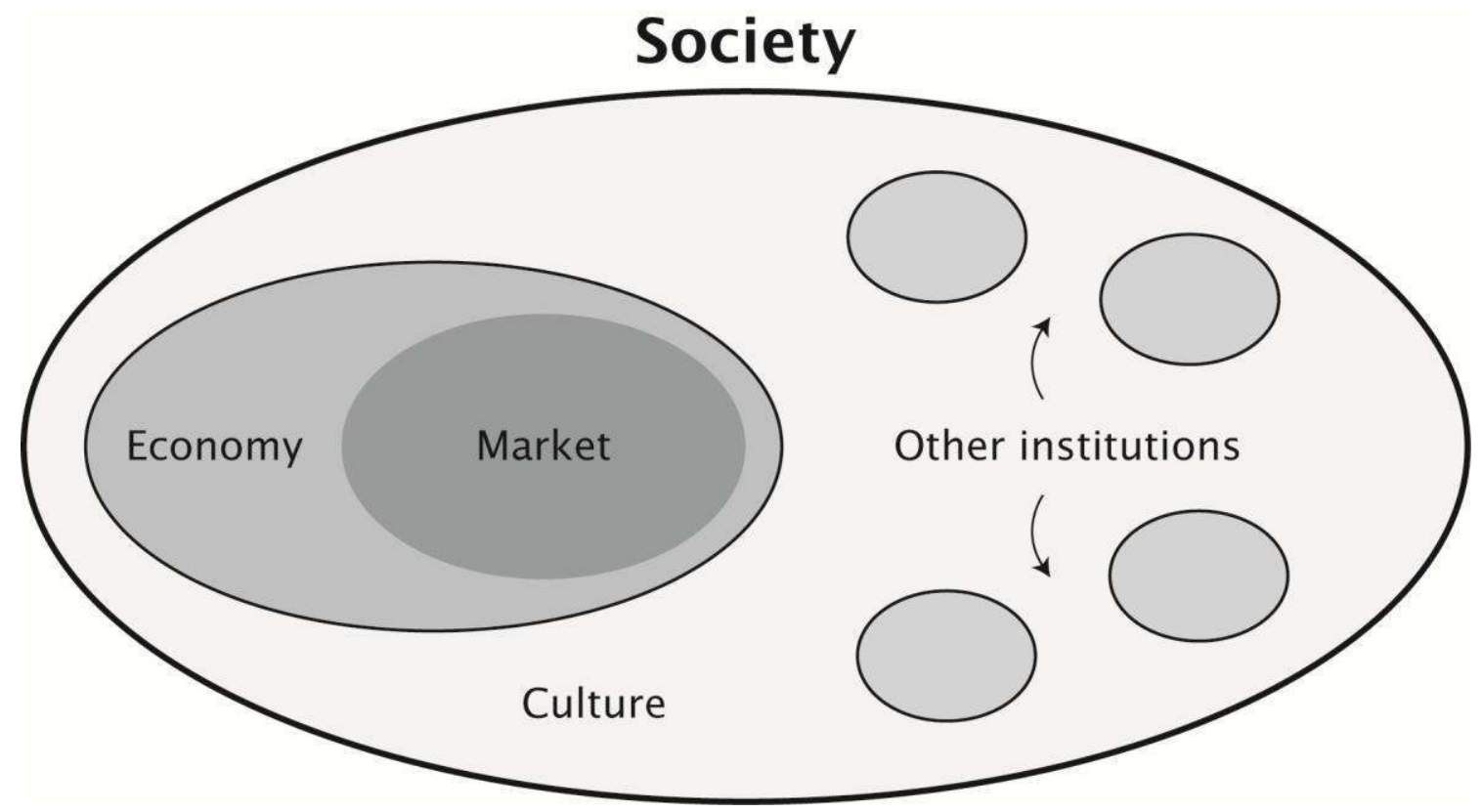

Figure 2 - Society as a differentiated sociocultural system Source: Bateira (2010)

This systemic view clearly shows that the provisioning of a society also depends to a large extent on non-market production, both public and private (Williams, 2005). We cannot insist too much on the fact that markets depend on the non-market economy, at least through the services that families provide to their members working in the market sub-system (Ortiz, 2002). Thus, non-market activity in any economy cannot be seen as a vestige of the past or as a minor complement to modern markets.

From this point of view, each market and the system of markets as a whole only exist in interaction with the state. In fact, not only are some markets created $a b$ initio by the state, no market functions without the normative framework that the state establishes and enforces. Thus the emergence of any market takes place within relations of interdependence

\footnotetext{
${ }^{12}$ See Polanyi: "The instituting of the economic process vests that process with unity and stability; it produces a structure with a definite function in society" (1957: 249, my italics).
} 
with the state, as well as with other markets, non-market production and the remaining institutions of society (Figure 3$)^{13}$

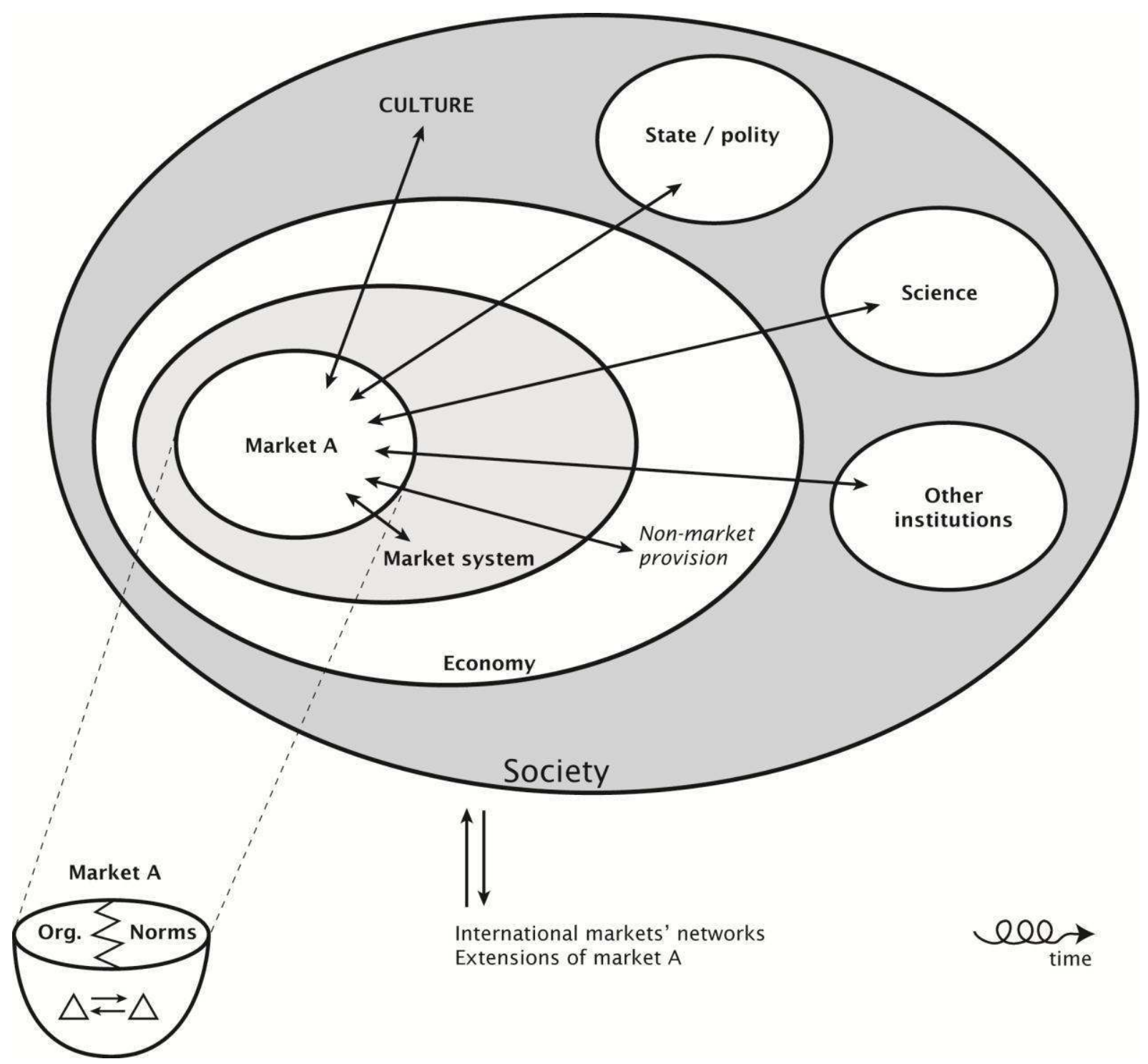

Figure 3 - The market and its interdependencies

Source: Bateira (2010)

Given that institutions are processes (flows) organized by causalities involving recursively interdependent structures and individuals, it makes no sense to speak of market equilibrium.

\footnotetext{
${ }^{13}$ It is not possible to give a full explanation of my concept of the market within the limits of this text. I shall merely point out that it is a multi-level system that includes not only the process of appropriation that arises from the purchase and sale of goods and services, but also processes of production, distribution and consumption. On this point, see Bateira (2010: 163-174).
} 
This notion was imported from mechanical physics, and cannot obviously be applied to social reality. Even so, the relative stability of the organization of the different processes constituting a market can and should be emphasised. The effects of negative feedback (buffering) that exist in all societies contribute to this stability, particularly the inertia that cultural structures introduce into the life of individuals and organizations (Veblen, 1994a).

This interactive view of the nature and functioning of markets points to the inadequacy of the endogenous/exogenous dichotomy, an analytical tool much used in mainstream economic theory. One example that emphasises the advantage of the interactivist approach, in this case in analysing the integration of a national economy into the global economy, is given by Campbell:

International pressures [...] are mediated by already existing domestic practices. New practices originating outside a country are translated, layered or otherwise recombined with nationally specific metatraditions that have been inherited from the past. [...] internationalization is a simultaneous move to universalism (convergence) and particularism (divergence). (2007: 181182)

In this institutionalist view of society, the state occupies the place of meta-institution that regulates the social system. It holds the monopoly on the production of laws and the use of force, whose control and administration is disputed by various social groups, some of which are organized into political forces subject to electoral scrutiny.

In treating the state as a meta-institution, I assume that it emerges from the interaction amongst individuals and diverse organizations (parliament, ministries, courts, the police, etc.). In the course of history, individual interactions consolidated the specific norms and social relations of this meta-institution which, once emergent, guarantee the interdependent autonomy amongst different types of state organization, as well as its systemic nature. In contrast to public choice theory (Buchanan \& Tullock, 1958), this text assumes that the rationality of civil servants and holders of political office, like that of other human beings, results from a complex of reasons and emotions that is far from being systematically selfish. The motivations of political agents are multiple and influenced by the national culture, by the culture of the organizations to which they are bound, by the exercise of power, by material interests, and also by altruistic interests, as with most citizens. ${ }^{14}$

\footnotetext{
${ }^{14}$ For a critique of rational choice theory, see Archer (2000) and Joas (1996). For a critique of public choice theory, see Udehn (1996).
} 
An institutionalist recognises that the state is not a neutral guardian of the general interest, nor has unlimited capacities to acquire all the knowledge that it needs to formulate policies or enforce them. However, accepting the limitations of civil servants, political leaders and state organizations does not imply accepting the thesis put forward by Mancur Olson (1965), for whom the state is, by nature, captured by economic interest groups (Mayhew, 2001). On the contrary, historical evidence shows that development processes were supported by states that also made wrong decisions and had bureaucracies that were far from perfect. As Chang aptly notes (2009: 19), "In the real world, successful countries are the ones that have managed to find 'good enough' solutions to their political economy problems and went on to implement policies, rather than sitting around bemoaning the imperfect nature of their political system." ${ }^{15}$

Even if we consider only production and exchange, the view of the market presented here goes far beyond the idea of a process of competition between firms through price. Since Alfred Marshall's analysis of 'industrial districts', we know that competition has always coexisted with entrepreneurial cooperation. Thus, the institutionalization of a culture of trust, favourable to cooperation, is an integral part of the informal norms that regulate the functioning of prosperous markets. Indeed, cooperation between companies, and between these and the state, is well documented in Lazonick's research (1991) on industrial development processes in the USA and Japan. By contrast, on the deregulation of markets, intensified after the 1970s, Chang claims that, "while there are some notable sectoral success stories, at least when seen from a static efficiency point of view, the often-expected dynamic benefits of deregulation at country-wide level do not seem to have materialised in any great quantity in most countries" (1997: 715-6).

As it is based on the interaction between markets and the other institutions in society, the political economy of Original Institutionalism is intrinsically sociocultural and historical. It is not reducible to an analysis of individualistic economic calculation centred on transaction costs and static efficiency gains, the analytical tools Williamson's New Institutionalism (1975) uses to discuss the nature of firms and markets. Original institutionalism broke with calculative reasoning, the concept of market equilibrium and the sterile simplism of

\footnotetext{
15 In overvaluing "state failures," mainstream economic theory has rejected the active role of the developmentalist state and, in its place, defended a regulatory state. This option has been argued in terms of static efficiency, concentrating on short-term results that are generally small and non-repeatable. At the same time, it ignores long-term results, particularly in productivity and growth. On this debate, see Chang (1997).
} 
algebraic formulas. Instead, it opens up a dialogue with the human sciences and with other fields of social science research.

The renewal of Original Institutionalism argued for here views economic development as a historical process of change in the structures of the economy, society and the interdependent relations that sustain them. Instead of seeking analogies with biology - one of Veblen's weak points which persists today in the work of some of his followers (Hodgson, 2004) - it is argued that institutionalist political economy should rather deepen the interdisciplinary dialogue and value the historical dimension of its object of study, paying particular attention to the German Historical School, for which Veblen had high regard.

\section{Conclusion}

The form of Original Institutionalism that I support views markets as (meso) institutions integrated into the economy as institution, in constant interaction with the other institutions of society, particularly with the meta-institution of the state. This leads to a new way of approaching state economic policy, which may be illustrated with a short note about the role of industrial policy in development processes.

Industrial policy has been described as a selective, arbitrary policy that provides financial support to some large companies or industries that the state defines as possessing high growth potential, sometimes in contradiction to their actual performance. Based on the existence of state failures, some have argued for a policy of indirect support, especially as regards education, R\&D and infrastructure expenses. As we have seen, the interactivist perspective of the relationship between the state and markets is more demanding.

The experience of the new industrialized countries shows that industrial policy is based on the strategic cooperation between the state and enterprises, chosen from a relatively open universe ("targeting within universalism") (Chang, 2009: 15). The success of these countries confirms that a relatively selective industrial policy, when directed towards capability building, is a powerful tool for economic development. Instead of distributing fiscal and financial benefits across industries, the interactive model proposes the creation of inter-institutional conciliation platforms involving public agents and entrepreneurs from specific industries with the goal of carrying out a common strategy. The aim of this process is to identify the obstacles to development raised by the culture of industry, by the training of 
workers and by the skills of entrepreneurs and state officials. More precisely, what needs to be discussed in the dialogue between the state and industry is the following:

(i) exactly why is, or isn't, industrial policy more difficult than other policies?; (ii) if it is more difficult than other policies, can it be made "easier" by learning from "best practices"? (iii) if it is not capabilities in mainstream economics, what exactly are the bureaucratic capabilities that are needed for good industrial policy?; (iv) how can we build those capabilities most quickly and cheaply? (Chang, 2009: 24-25)

The critics of an industrial policy of a developmentalist state will be tempted to raise the following question: how is it possible that politicians and ministry staff, without any business experience, are in a condition to discuss with entrepreneurs a strategy for their industry? Actually, the interactivist model of economic policy starts from a more realistic understanding of what knowledge is: it is not something that one does (or does not) have, but rather a personal capacity that is developed through social interaction. In the process of designing an industrial strategy, state agents have certainly a great deal to learn, but the same may be said of entrepreneurs. The experience of the newly industrialized countries shows that the former "could look at things from a national and long term point of view, rather than sectional, short-term point of view" (Chang, 2009: 16), which is essential when the aim is to build individual and organizational capabilities and renovate institutions and culture.

This institutionalist perspective on development compels us to critically challenge the EU policies designed to support structural change in the so-called "cohesion countries." In Portugal, after more than a decade of massive financial assistance, the problem of the external deficit remains, and has given rise to an accumulation of private and public debt that has made the country bankrupt. The present Euro-zone crisis makes us realise that the EU's strategy to promote the real convergence of these countries has been a failure.

However, it is important to understand that this failure cannot be overcome without a revolution in the present legal framework of the EU. Indeed, the letter and spirit of the Treaties prevent an industrial policy in the terms mentioned above, at least as regards competition and free trade. The truth is that a EU country, particularly if it is in the Eurozone, does not have the autonomy to implement a developmental economic policy. However, as Chang reminds us, "Policy space is a matter of vital importance. Long-range historical records suggest that it has an enormous influence on a country's ability to achieve 
economic development" (2005: 19). If this is true, then Portugal's integration into the EU is at the centre of the crisis in which the Portuguese find themselves today.

Translated by Karen Bennett

Revised by Teresa Tavares

\section{References}

Ackerman, Frank (2004), "Still Dead After All These Years: Interpreting the Failure of General Equilibrium Theory," in Frank Ackerman and Alejandro Nadal (eds.), The Flawed Foundations of General Equilibrium - Critical Essays on Economic Theory. London \& New York: Routledge, 14-32.

Acocella, Nicolas (2000), The Foundations of Economic Policy: Values and Techniques. Cambridge, UK: Cambridge University Press.

Archer, Margaret (2000), Being Human: The Problem of Agency. Cambridge, UK: Cambridge University Press.

Bandura, Albert (2001), "Social Cognitive Theory: An Agentic Perspective," Annual Review of Psychology, 52: 1-26.

Bateira, Jorge (2006), "Beyond the Codification Debate: A Naturalist View of Knowledge," in Wilfred Dolfsma and Luc Soete (eds.), Understanding the Dynamics of a Knowledge Economy. Cheltenham, UK/Northampton, MA, USA: Edward Elgar, 222-250.

Bateira, Jorge (2010), "Institutions, Markets and Economic Evolution - Conceptual Basis for a Naturalist Institutionalism." PhD Dissertation, Manchester Business School, The University of Manchester, UK.

Buchanan, James M.; Tullock, Gordon (1958), The Calculus of Consent: Logical Foundations of Constitutional Democracy. Indianapolis, IN: Liberty Fund Inc.

Campbell, John L. (2007), "Complexity and Simplicity in 'The Global and the Local'," Socio-Economic Review, 5 (Review Symposium): 181-186.

Campbell, Robert (2009), "A Process-Based Model for an Interactive Ontology," Synthese, 166: 453477.

Chang, Ha-Joon (1997), "The Economics and Politics of Regulation," Cambridge Journal of Economics, 21: 703-728.

Chang, Ha-Joon (2002), "Breaking the Mould: An Institutionalist Political Economy Alternative to the Neo-Liberal Theory of the Market and the State," Cambridge Journal of Economics, 26: 539-559.

Chang, Ha-Joon (2005), "Policy Space in Historical Perspective - With Special Reference to Trade and Industrial Policies." Paper presented at the Queen Elizabeth House 50th Anniversary Conference. Accessed on 16.03.12 at http://www.networkideas.org/featart/sep2005/Policy Space.pdf.

Chang, Ha-Joon (2007), Bad Samaritans: The Guilty Secrets of Rich Nations and the Threat to Global Prosperity. London: Random House.

Chang, Ha-Joon (2009), "Industrial Policy: Can We Go beyond an Unproductive Confrontation?" Plenary lecture at the Annual World Bank Conference on Development Economics, Seoul, South Korea, 22-24 June. Accessed on 16.03 .12 at http://siteresources.worldbank.org/INTABCDESK2009/Resources/Ha-Joon-Chang.pdf. 
Damásio, António (1999), The Feeling of What Happens: Body and Emotion in the Making of Consciousness. New York: Harcourt Brace \& Company.

Hodgson, Geoffrey M. (2004), The Evolution of Institutional Economics. Agency, Structure and Darwinism in American Institutionalism. London \& New York: Routledge.

Hodgson, Geoffrey M. (2008), "Markets," in John Davis and Wilfred Dolfsma (eds.), The Elgar Companion to Social Economics. Cheltenham, UK/Northampton, MA: Edward Elgar Publishing, 251-266.

Hopkins, Terence K. (1957), "Sociology and the Substantive View of the Economy," in Karl Polanyi, C. M. Arensberg and H. W. Pearson (eds.), Trade and Market in the Early Empires: Economies in History and Theory. Glencoe, III.: The Free Press, 271-306.

Joas, Hans (1996), The Creativity of Action. London: Polity Press.

Kilpinen, Erkki (2003), “Does Pragmatism Imply Institutionalism?" Journal of Economic Issues, 37(2): 291-304.

Kirman, Alan (1989), "The Intrinsic Limits of Modern Economic Theory: The Emperor Has no Clothes," Economic Journal, 99(395): 126-39.

Lazonick, William (1991), Business Organization and the Myth of the Market Economy. Cambridge, UK: Cambridge University Press.

Liebhafsky, E. E. (1993), "The Influence of Charles Sanders Peirce on Institutional Economics," Journal of Economic Issues, 27(3): 741-754.

Mayhew, Anne (2001), "Human Agency, Cumulative Causation, and the State. Remarks upon Receiving the Veblen-Commons Award," Journal of Economic Issues, 35(2): 239-250.

Mirowski, Philip (1987), "The Philosophical Bases of Institutionalist Economics," Journal of Economic Issues, 21(3): 1001-1038.

Olson, Mancur (1965), The Logic of Collective Action: Public Goods and the Theory of Groups. Cambridge, Mass.: Harvard University Press.

Ortiz, Sutti (2002), "Work, the Division of Labour and Co-operation," in Tim Ingold (ed.), Companion Encyclopedia of Anthropology. London: Routledge, 891-910.

Polanyi, Karl (1944), The Great Transformation. Political and Economic Origins of our Time. Boston, MA: Beacon Press.

Polanyi, Karl (1957), "The Economy as Instituted Process," in Karl Polanyi, C. M. Arensberg and H. W. Pearson (eds.), Trade and Market in the Early Empires: Economies in History and Theory. Glencoe, III.: The Free Press, 243-270.

Rescher, Nicholas (2000), Process Philosophy: A Survey of Basic Issues. Pittsburgh, PA: University of Pittsburgh Press.

Rescher, Nicholas (2004), "Pragmatism and Practical Rationality," Contemporary Pragmatism, 1(1): 43-60.

Rizvi, S. Abu Turab (2006), "The Sonnenschein-Mantel-Debreu Results after Thirty Years," History of Political Economy, 38 (annual supplement): 228-245.

Silberstein, Michael (2002), "Reduction, Emergence and Explanation," in Peter Machamer and Michael Silberstein (eds.), The Blackwell Guide to the Philosophy of Science. Oxford: Blackwell, 80107.

Simon, Herbert A. (1959), "Theories of Decision-Making in Economics and Behavioral Science," The American Economic Review, 49(3): 77-107. 
Smith, Vernon L. (2008), Rationality in Economics. Constructivist and Ecological Forms. New York: Cambridge University Press.

Tovar, Camilo E. (2008), "DSGE Models and Central Banks," BIS Working Papers, 258, Basel, Switzerland. Accessed on 16.03.12 at http://www.economicsejournal.org/economics/journalarticles/2009-16.

Udehn, Lars (1996), The Limits of Public Choice: A Sociological Critique of the Economic Theory of Policies. London \& New York: Routledge.

Vatn, Arild; Bromley, Daniel W. (1997), "Externalities - A Market Model Failure," Environment and Resource Economics, 9: 135-151.

Veblen, Thorstein (1994a), The Theory of the Leisure Class: An Economic Study of Institutions. Vol. 1 of The Collected Works of Thorstein Veblen. London: Routledge/Thoemmes Press [ $1^{\text {st }}$ ed.: 1899].

Veblen, Thorstein (1994b), "The Limitations of Marginal Utility," The Place of Science in Modern Civilization and Other Essays. Vol. 8 of The Collected Works of Thorstein Veblen. London: Routledge/Thoemmes Press [original publication: 1909].

Vira, Bhaskar (1997), "The Political Coase Theorem: Identifying Differences between Neoclassical and Critical Institutionalism," Journal of Economic Issues, 31(3): 761-779.

Weissman, David (2000), A Social Ontology. New Haven, CT: Yale University Press.

Whitford, J. (2002), "Pragmatism and the Untenable Dualism of Means and Ends: Why Rational Choice Theory Does not Deserve Paradigmatic Privilege," Theory and Society, 31: 325-363.

Williams, Colin C. (2005), A Commodified World? Mapping the Limits of Capitalism. London/New York: Zed Books.

Williamson, Oliver (1975), Markets and Hierarchies: Analysis and Antitrust Implications. New York: The Free Press. 